\title{
Edmodo in Blended Learning to Increase Language Learners' Understanding in Learning Grammar for Toefl
}

\author{
Siti Qomariyahํㅡㄹ Gunarhadi², Triana Rejekiningsih ${ }^{3}$
}

\begin{tabular}{l} 
ARTICLE INFO \\
\hline Article History: Received \\
30.09.2018 Received in \\
revised form \\
22.11 .2018 \\
Accepted \\
Available online 01.01 .2019
\end{tabular}

\section{INTRODUCTION}

The expansion of the technology in this era which is called era Revolution 4.0 gives many changes in every aspect of the live more over in increasing the quality of the education. New and new information come to people every day. People need to deal with the changing environment in order to catch up the gap betw een the school and the w orkplace. The traditional division of a lifetime is not appropriate for the current and the future education people (Yurdakul, 2017). Smart Education is a new paradigm in global education that goal to increase the quality of the students in long life learning. Many factors that will influence the development of the education in the future, among of them is the development of the technology that grows faster and faster. Besides, the development of information technology and the rivalry to get a job that marked with the development of new technology which increasing of the competency. In this case, the renewal in the education need to be developed on and on and become a never-ending process (Wardani, 2018).

The never-ending process in education is a must as the technology develop because it will be left behind without following this expansion of technology. As the technology now facilitate the learners and the teacher to have a class without face to face meeting in the class but by online class using any kind of the product of the technology. On the other hand, the development of the technology and digitalization make the students able to access the information needed easily, if the teachers' role is just transferring the knowledge days by day will be replaced by the technology. In addition, that not all aspect can be replaced by the technology, such as book which is still become an effective learning source. Besides, the existence of the teacher in the class as conventional class cannot be replaced by any kind of technologies (Wuriandana, 2016).

In traditional learning or conventional class, teacher is the center of learning process and the students are mostly passive learners. Therefore, the teacher only taught what was is inside the book and the students inquired to listen to the lesson and pay attention with almost negligible participation in the class but for the expansion of the technology now the students can get many sources and information they want easily (Mohammed, 2018). In this case the combination between the technology and conventional class are needed to deal with the development of the technology which is called blended learning. Many kinds of technologies than have been available that the teacher can be chosen by the teacher, one of them is Edmodo (Qomariyah, 2018).

${ }^{1}$ Corresponding e-mail: seeteaq@gmail.com, ${ }^{1,2,3}$ Sebelas Maret University, orcid.org/0000-0002-5486-6905 
Edmodo is a free social learning platform that provides a safe way for students and teachers to connect and collaborate. Edmodo is a private social networking for the teacher and students with save social platform. The model of Edmodo similar to other social network, Edmodo can be a special network special for the teacher and students to share ideas, file, news, and assignment (Shelly, 2011). While others said that Edmodo is a social network and a microblogging which was designed special for education that can be operated similar to other social network like Twitter. By limiting the access to special group, teacher and students can share note, link, file, announcement, assignment, and share the information in the familiar environment (Wankel, 2011).

Edmodo is an educational netw ork that aims at providing teachers with tools to help them connect and communicate with their students and parents. Via the Edmodo app or website, teacher can share content, texts, videos, homew ork and assignments with their students online. It is designed to get students excited about learning in familiar environment. On Edmodo teachers can continue classroom discussions online, give polls to check for the student understanding, and award badges to individual students based on performance or behavior. Its surfaces up engaging, easy-to-use apps that personalize learning for every students. These apps help teachers to amplify their lesson plans and integrate seamlessly with Edmodo, delivering all digital content in one place. It also gives easy for the teachers to track students progress. All grade or awarded through Edmodo are stored and easily accessible. Teachers can get the pulse of their classroom through reactions to quizzes, assignments, and discussion posts that capture understanding, confusion, or frustation. İ is a social network platform that design special for education with the display similar to Facebook. İt is simple, easy, and can be used by the learners (students), teachers, or even by parents (Usman, 2016).

Many studies about Edmodo used in blended learning that applied in learning subject in the formal education (Balasubramanian, et al, 2014; Marzal, 2014; Mokhtar, 2016, Wich adee, 2017), but in this study is about the application of blended learning using Edmodo in learning structure or grammar which is focused in grammar in TOEFL in one of the biggest English courses in 'Kampung Inggris' Pare Kediri. This place was chosen because many language learners from other city in Indonesia even from abroad come to this place to learn English. Pare is a sub-district in Kediri East Java.

\section{Situation of the Problem}

As in introduction has already been explained that many language learners (students) from many different places, religions, customs, and cultures even from other countries come to 'Kampung Inggris' to learn English with various basics that they had, but they have same goal come to this place. The problem is then that in almost every course in 'Kampung Inggris' use conventional class without any technology at all except some programs that require some special tool such as LCD projector and sound system. Besides, the teaching learning process used is teacher center where the teacher is the source of any kind of information especially in grammar class or program. In addition, the students need exercise more in learning grammar TOEFL with timer to train them to think and do fast in answering the questions given so that it will become their habit when they join in official TOEFL test.

\section{Aim of the Study}

Aim of this study is to determine the language learners' understanding of the students' English course in 'Kampung Inggris' Pare Kediri. As it is already stated above that the objective of this study is to answer following questions, those are: (1) How w as the teaching learning process in grammar TOEFL class now , (2) How is teaching learning process of grammar TOEFL using Edmodo in blended learning applied, (3) how is the effect of Edmodo in blended learning in increasing students' understanding in learning grammar TOEFL.

\section{METHOD}

This study is a qualitative with One-Group pretest-posttest design so that $t$-test was used to know the different mean between pretest and posttest. The objective of this study is to find out the language learners' understanding in learning grammar TOEFL through having discussion more in the conventional class or face to face class and do exercise using timer in Edmodo, so that the students can do the final test on time as in the official TOEFL test. This study only took one class consisting of 25 students which was heterogender 
class around 19-23 years old that came from many different ethnics, cities, educations, and cultures in Global English Pare, one of the biggest English courses in 'Kampung Inggris' Pare Kediri.

The instrument of this study is test which was to know the students' score before and after the treatment given to them. The tests were taken from the exercise of TOEFL test that consist of 40 multiple choice questions that must be done in 25 minutes. The data that was used is quantitative data primer from pretest and posttest.

\section{RESULT}

The data in this study was got from the score of pretest dan posttest that was done before and after the treatment given. There were 40 questions in pretest and posttest that consist of 15 numbers were incomplete sentences and others 25 are written expression or error analysis. the students' correct answer then converted with the conversion table score of TOEFL. If the students can answer 40 question correctly he/she will get 680.

\section{Students' pretest score}

The beginning score of the students $w$ as got from pretest that $w$ as done before the treatment $w$ as given. The number of students join in pretest w as 25 students. From the distribution frequency score of pretest was known that $0 \%$ or no one in very good category, $40 \%$ or ten students were categorized in the good, $52 \%$ or thirteen students were categorized in enough, and $8 \%$ or two students were categorized in less. The highest score in the pretest was 500 and the lowest one was 300 from the maximum score in TOEFL is 680.

Table.1. Score Category

\begin{tabular}{cc}
\hline Score & Category \\
\hline $\mathbf{5 5 0 - 6 8 0}$ & Very Good \\
$\mathbf{4 5 0 - 5 4 0}$ & Good \\
$\mathbf{3 5 0 - 4 4 0}$ & Enough \\
$\mathbf{2 0 0 - 3 3 0}$ & Less \\
\hline
\end{tabular}

Table.2. Pretest score

\begin{tabular}{|c|c|c|}
\hline No & Name & Pretest Score \\
\hline 1 & A.K & 400 \\
\hline 2 & A.R.A & 340 \\
\hline 3 & A.U.F & 470 \\
\hline 4 & D.N.A & 360 \\
\hline 5 & D.S.A.I & 460 \\
\hline 6 & E.V & 370 \\
\hline 7 & F.U.P & 300 \\
\hline 8 & $\mathrm{~F}$ & 430 \\
\hline 9 & F.A & 490 \\
\hline 10 & G.O.F & 410 \\
\hline 11 & H.G.S & 370 \\
\hline 12 & K.D & 400 \\
\hline 13 & M.A.Z & 450 \\
\hline 14 & M.F.P.S.S & 500 \\
\hline 15 & M.I & 400 \\
\hline 16 & M.P.F & 450 \\
\hline 17 & M.R & 460 \\
\hline 18 & M.T.H.A & 370 \\
\hline 19 & N.F.A.N & 420 \\
\hline 20 & N.Y & 310 \\
\hline 21 & R.M & 500 \\
\hline 22 & R.Y.S & 500 \\
\hline 23 & S.P.R.B & 380 \\
\hline 24 & S.N.N.A & 430 \\
\hline 25 & Z.A.B & 480 \\
\hline & Mean & 418 \\
\hline
\end{tabular}




\section{Students' final score (posttest)}

Final data were got from the result score of posttest that was done after the repetitions treatments were given to the class. The number of students who joined in the posttest $w$ as same as in the pretest, and so did the number of the questions that was 25 students and 40 questions in 25 minutes.

Table.3. Posttest score

\begin{tabular}{|c|c|c|}
\hline No & Name & Posttest Score \\
\hline 1 & A.K & 450 \\
\hline 2 & A.R.A & 510 \\
\hline 3 & A.U.F & 530 \\
\hline 4 & D.N.A & 410 \\
\hline 5 & D.S.A.I & 520 \\
\hline 6 & E.V & 400 \\
\hline 7 & F.U.P & 530 \\
\hline 8 & $\mathrm{~F}$ & 470 \\
\hline 9 & F.A & 500 \\
\hline 10 & G.O.F & 530 \\
\hline 11 & H.G.S & 510 \\
\hline 12 & K.D & 430 \\
\hline 13 & M.A.Z & 540 \\
\hline 14 & M.F.P.S.S & 560 \\
\hline 15 & M.I & 430 \\
\hline 16 & M.P.F & 430 \\
\hline 17 & M.R & 550 \\
\hline 18 & M.T.H.A & 470 \\
\hline 19 & N.F.A.N & 500 \\
\hline 20 & N.Y & 400 \\
\hline 21 & R.M & 540 \\
\hline 22 & R.Y.S & 520 \\
\hline 23 & S.P.R.B & 440 \\
\hline 24 & S.N.N.A & 510 \\
\hline 25 & Z.A.B & 520 \\
\hline \multicolumn{2}{|r|}{ Mean } & 488 \\
\hline
\end{tabular}

\section{Chart.1. The Comparison Score Pretest and Posttest}

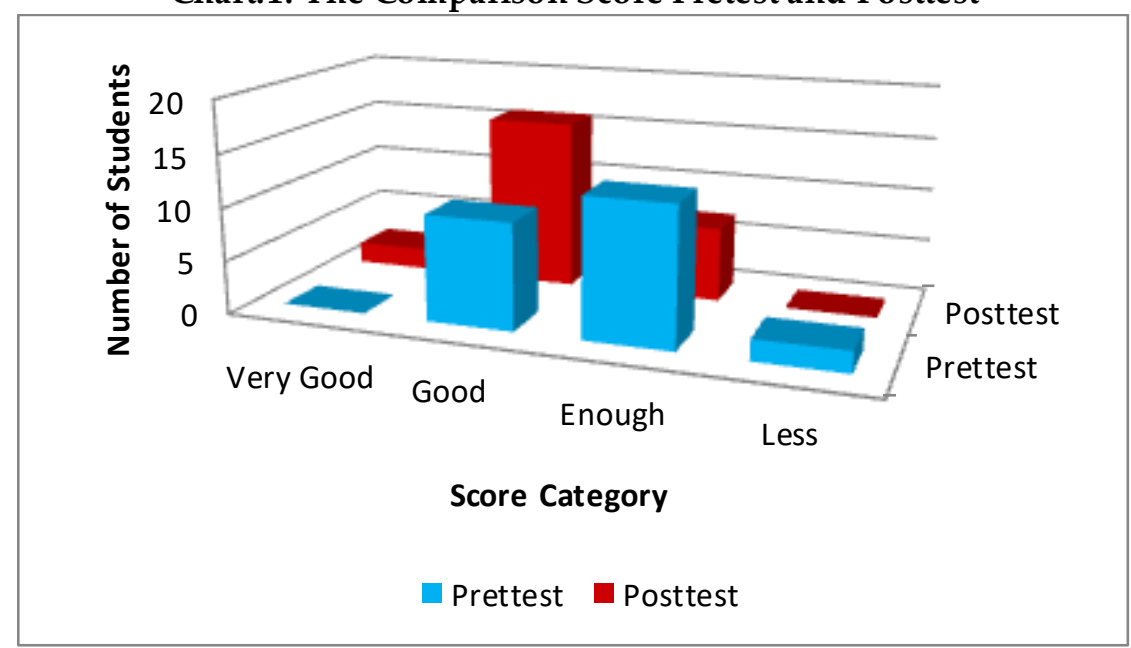

From the calculation of frequency distribution showed that $8 \%$ of the students or two students are in the category very good, $64 \%$ or sixteen students are in the good category, $28 \%$ or seven students are in enough category, and $0 \%$ or no one in the less category. The highest score of posttest was 560 and the lowest one was 400 from the maximum score in TOEFL. It can be seen from the data above that final score of the students increase compare with the pretest score. 


\section{DISCUSSION AND SUGGESTION}

The constructivist views which states that learning is a process of knowledge formation. The formation must be done by the learner (student). Students must be active in activities, actively in thinking, constructing concepts and give meaning according to their ow $n$ understanding of the subject being studied. A meaningful learning process will be formed if the teacher not only provides knowledge to students but also provides opportunities for students to build their own knowledge through the process of discovering and applying concepts that students have understood themselves (Budiningsih, 2012). Edmodo- based learning in blended learning is provided to help the formation of knowledge by students. The use of Edmodo effective because Edmodo has several features, those are: (1) Adapting the appearance like Facebook, so it is motivated the students to learn more, (2) Edmodo supports previewing various types of file formats, and (3) Edmodo not only can be accessed using a PC (laptop/desktop) but it can also be accessed using gadget.

Edmodo in blended learning can support in the teaching learning process that fun and interesting for the students also tighten their motivation and spirit also the students' attention as well. Those are can be seen in the result of the exercises given in Edmodo every day that will be discuss in the next meeting in the face to face classroom activity. The students who active in doing the exercise will have good understanding in the lesson because they have read the material and done the exercises given in Edmodo. It mean that Edmodo can bring the changes in the teaching leaning process, because at the previous the center of the teaching learning process was the teacher or teacher-centered become student-centered. The teacher, in this case become a facilitator, inspirator, and motivator for the students. The process will make teaching learning process more active than before.

This study is also supported by the previous one about Edmodo in teaching learning process, among of them are Wichadee, 2017 and Dharmaw ati, 2017. Saovapa stated that Edmodo not only has a great benefit in improving listening skill through the audio files uploaded but it is also a simple tool for blended learning, while Dharmawati said if using Edmodo make the students active in teaching learning process. Hopefully the using of Edmodo in teaching learning process can be applied in other skill of learning English such as reading, writing, and soon. Besides it also can be used in other subjects.

From the result got above, it is better for the teachers who want to applied Edmodo in their teaching learning process to make good preparation in it, includes the material, the internet connectivity, many types of the students' exercises both uploaded in Edmodo and printed well for the language learners exercises especially in 'Kampung Inggris' Pare Kediri.

\section{REFERENCES}

Balasubramania, K., Jaykumar, \& Fukey, L.N. (2014). A study on student preference towards the use of edmodo as a learning platform to create responsible learning environtment. Procedia-Social and Behavioral Sciences, 144, 416-422.

Budiningsih, C. (2012). Belajar dan Pembelajaran. Jakarta: Rineka Cipta.

Dharmawati. (2017). Penggunaan Media e-Learning Berbasis Edmodo Dalam Pembelajaran English for Business. QUERY: Jurnal Sistem Informasi, 1, 43-49.

Marzal, J. (2014, April). Studi Penggunaan Jejaring Sosial Edmodo Sebagai Media E-Learning Oleh Dosen Senior Ynag Tidak Terbiasa Bekerja Dengan Komputer. Edumatica, 4, 37-43.

Mohammed, G.S., Wakil, K, \& Naw roly, S.S. (2018). The effectiveness of microlearning to improve students' learning ability. International Journal of Educational Research Review (IJERE), 3(3), 32-38.

Mokhtar, F.A. (2016). Rethinking conventional teaching in language learning and proposing edmodo as intervention: A qualitative analysis. MOJET: Malaysian Online Journal of Education Technology, 4(2), 22-37.

Qomariyah, S. (2018). Pengembangan Model Pembelajaran Untuk Meningkatkan Penguasaan Grammar TOEFL Berbasis Blended Learning Menggunakan Edmodo Di Lembaga Kursus Global English Pare Kediri.

Shelly, Gary, et al. (2011). Teachers discovering computers: Integrating technology in a connected world. Bosto: Cengange Learning. 
Qomariyah,S., Gunarhadi \& Rejekiningsih,T.(2019).Edmodo in blended learning to increase language learners' understanding in

learning grammar for Toefl. Interna tional Journal of Educational Research Review,4(1),82-87.

Sugiyono. (2005). Metode Penelitian Pendidikan Pendekatan Kuantitatif, Kualitatif dan RED. Bandung: Alfabeta.

Usman. (2016). E-Learning Berbasis Edmodo Dalam Pengajaran Bahasa Inggris Pada Jurusan Akuntansi Politeknik Negeri Samarinda. Jurnal Eksis, 12(1), 3295-3298.

Wankel, C. (2011). Educating educators with social media. United Kingdom: Emerald Group Publishing Limited.

Wardani, R. (2018). 21st Century Educator: Menyongsong Transformasi Pendidikan 4.0. (S. N. Upy, Performer)

Wichadee, S. (2017). A development of the blended learning model using edmodo for maximizing students' oral proficiency and motivation. iJET, 12(2), 137-154.

Wuriandana, I. (2016). https://news.okezone.com/read/2016/06/22/65/1422418/. Retrieved from hanya-mengajarguru-bisa-tergantikan-oleh-teknologi.

Yurdakul, C. (2017). An investigation of the relationship between autonomous learning and lifelong learning. International Journal of Educational Research Review (IJERE), 2(1), 15-20. 